Article

\title{
Lanthanum Nickel Oxide: An Effective Heterogeneous Activator of Sodium Persulfate for Antibiotics Elimination
}

\author{
Athanasia Petala ${ }^{1, *(D)}$, Olga S. Arvaniti ${ }^{1}$, Maria Christofili ${ }^{1}$, Alexandros Safakas ${ }^{1}$, \\ Zacharias Frontistis $^{2}$ and Dionissios Mantzavinos ${ }^{1}$ D \\ 1 Department of Chemical Engineering, University of Patras, Caratheodory 1, University Campus, \\ GR-26504 Patras, Greece; olga.arvan@gmail.com (O.S.A.); mariaxristofilly@gmail.com (M.C.); \\ asafakas@chemeng.upatras.gr (A.S.); mantzavinos@chemeng.upatras.gr (D.M.) \\ 2 Department of Chemical Engineering, University of Western Macedonia, GR-50132 Kozani, Greece; \\ zfrontistis@uowm.gr \\ * Correspondence: natpetala@chemeng.upatras.gr; Tel.: +30-2610997223
}

Received: 28 October 2020; Accepted: 24 November 2020; Published: 25 November 2020

\begin{abstract}
In recent years, the presence of pharmaceutically active compounds (PhACs) in surface waters and wastewaters has $b$ the effectiveness of conventional water treatment methods. Towards this direction, advanced oxidation processes (AOPs) for the complete elimination of micro pollutants in waters have become an emerging area of research. The present study reports the heterogeneous activation of sodium persulfate (SPS) by $\mathrm{LaNiO}_{3}$ (LNO) perovskite oxide for the degradation of sulfamethoxazole (SMX), an antibiotic agent. LNO was prepared according to a combustion method, and its physicochemical characteristics were identified by means of XRD, BET, TEM, and SEM/EDS. SMX degradation results showed the great efficiency of LNO for SPS activation. Increasing LNO and SPS dosage up to $250 \mathrm{mg} / \mathrm{L}$ enhanced the SMX degradation. In contrast, increasing SMX concentration resulted in longer time periods for its degradation. Considering the $\mathrm{pH}$ effect, SMX removal was obstructed under basic conditions, while the efficiency was enhanced at near-neutral conditions. The present system's activity was also tested for piroxicam (PIR) and methylparaben $(\mathrm{MeP})$ degradation, showing promising results. Unfortunately, experiments conducted in real water matrices such as bottled water (BW) and wastewater (WW), showed that SMX removal was limited to less than $25 \%$ in both cases. The hindering effects were mainly attributed to bicarbonate ions and organic matter present in aqueous media. The results obtained using suitable radical scavengers revealed the contribution of both hydroxyl and sulfate radicals in degradation reactions. Finally, LNO exhibited good stability under consecutive experimental runs.
\end{abstract}

Keywords: lanthanum nickel oxide; perovskite; persulfate; antibiotics; sulfamethoxazole; water matrix

\section{Introduction}

In recent years, advanced oxidation processes (AOPs), based mainly but not exclusively on the in-situ formation of hydroxyl radicals $(\bullet \mathrm{OH})$, have been considered as a promising family of technologies for the complete degradation of persistent micropollutants in aqueous media [1]. Some characteristic examples include phenolic compounds photocatalytic removal, [2], antibiotics degradation by Fenton and Fenton-like processes [3], and polyfluorinated alkyl substances (PFASs) electrochemical oxidation [4].

A subcategory of AOPs attracting great scientific interest includes the formation of sulfate radicals $\left(\mathrm{SO}_{4}^{\bullet-}\right)$ as the main oxidative species, known as sulfate radical-based AOPs (SR-AOPs) [5,6]. The $\mathrm{SO}_{4}^{\bullet-}$ functionality over a wide $\mathrm{pH}$ range [7] and its relatively long half-life time compared to hydroxyl 
radicals, probably contribute to effective water decontamination in many systems. Moreover, the safe storage of persulfate salts [8] makes this technology very attractive for industrial applications.

$\mathrm{SO}_{4}^{\bullet-}$ are conventionally produced through energy input in the form of heat or UV irradiation to persulfates, resulting in the fission of $\mathrm{O}-\mathrm{O}$ bond in their structure and the formation of radicals [9]. Moreover, $\mathrm{SO}_{4}^{--}$can be produced either homogeneously or heterogeneously through reactions with transition metals [10]. In that case, energy requirements are significantly reduced, thus lowering the cost of the treatment. Moreover, in heterogeneous systems, the non-occurrence of metal ions in aqueous solutions prevents the secondary contamination of water [11], thus multiplying the benefits of the process. Cobalt and copper-based oxides have already stood out as heterogeneous activators characterized by high efficiency towards persulfate activation [12,13]. Specifically, $\mathrm{CuO}$ was successfully used for peroxydisulfate activation, without producing sulfate radicals, with copper leaching remaining the main drawback of the process [12]. Moreover, Lei et al., synthesized $\mathrm{CuO}-\mathrm{Fe}_{3} \mathrm{O}_{4}$ composites for persulfate activation towards phenol degradation [13]. They observed that the system was favored in case of bicarbonate ions and basic conditions, increasing its effectiveness in wastewater. However, the use of high persulfate dosage $(1200 \mathrm{mg} / \mathrm{L})$ and long time periods for phenol degradation (120 min) limited the practical value of the proposed system [13].

Our group recently pointed out that, apart from metal oxides, other formulations such as metal phosphides [14] and perovskites [15] could be suitable SPS activators. Copper phosphide $\left(\mathrm{Cu}_{3} \mathrm{P}\right)$ showed great efficiency towards persulfate activation, leading to complete SMX removal in very short time periods [14]. However, experiments carried out in real water matrices (bottled water, treated wastewater) revealed severe hindering phenomena in SMX elimination [14]. This was also the case when lanthanum strontium cobaltite $\left(\mathrm{La}_{0.8} \mathrm{Sr}_{0.2} \mathrm{CoO}_{3-\delta}\right)$ was used as a persulfate activator, with the efficiency of the process being significantly reduced in real aqueous media [15].

While perovskite materials enjoy great popularity in catalysis [16] and solid oxide fuel cells [17], their usage in chemical oxidation processes is still quite limited [18]. Moreover, amongst perovskites, cobalt-based materials have been studied almost exclusively as persulfate activators [19-21]. In specific, Hammouda et al. prepared a series of cobalt based-perovskite catalysts $\mathrm{ACoO}_{3}(\mathrm{~A}=\mathrm{La}, \mathrm{Ba}, \mathrm{Sr}, \mathrm{Ce})$ and studied phenol degradation by means of potassium monopersulfate activation [19]. Phenol degradation was also studied using perovskite-like oxides $\mathrm{SrCo}_{1-\mathrm{x}} \mathrm{Ti}_{\mathrm{x}} \mathrm{O}_{3-\delta}\left(\mathrm{SCT}_{\mathrm{x}}, \mathrm{x}=0.1,0.2,0.4,0.6\right)$ to activate peroxymonosulfate (PMS), showing greater efficiency than $\mathrm{Co}_{3} \mathrm{O}_{4}$ and $\mathrm{TiO}_{2}$ [20]. Moreover, a series of $\mathrm{LaCoO}_{3}$ perovskites were used as catalysts for PMS activation for 2-phenyl-5-sulfobenzimidazole acid degradation, showing promising results [21]. However, none of the above-mentioned studies did not investigate the efficiency of the proposed systems under realistic conditions [19-21], thus lowering their practical value.

To shed light to the role of metal in perovskite materials in persulfate activation, nickel-based perovskite is studied as a heterogeneous sodium persulfate (SPS) activator in the present work. As far as we know, apart from very few studies presenting Ni-mixed oxides [22,23], this is the first time that Ni-perovskite is used for SPS activation towards pharmaceuticals removal from water.

The $\mathrm{LaNiO}_{3}$ (LNO) oxides and similar materials with partial substitution of $\mathrm{B}$ site by other transition metals such as chromium, cobalt, iron, and manganese, have been extensively studied as electrocatalysts for the oxygen reduction reaction/oxygen evolution reaction (ORR/OER) in electrochemical applications. More specifically, LNO perovskites have been tested as cathodes in solid oxide fuel cells [24], electrocatalysts for ORR in fuel cells, and bifunctional catalysts (OER/ORR) for regenerative fuel cells and metal-air batteries $[25,26]$. Furthermore, they have also been evaluated as cathodes in direct borohydride fuel cells [27]. Nanoscale LNO sheets, hallow spheres and randomly shaped crystals have been tested as electrode materials in supercapacitors technology [28], while LNO composite nanofibers in supercapacitors and p-type gas sensors too [29]. In heterogeneous catalysis, LNO oxides have been examined as catalysts or catalyst precursors in various reactions, as potential substitutes to the expensive and rare noble metals. This includes some widely studied reactions such as $\mathrm{CO}$ oxidation, methane oxidation/partial oxidation, methane dry reforming, and steam reforming of ethanol [30]. 
In photocatalysis, there are few reports investigating LNO composite materials towards hydrogen evolution reaction (HER) [31].

In the present study, LNO was synthesized according to a combustion method followed by calcination at $700{ }^{\circ} \mathrm{C}$ for $2 \mathrm{~h}$. Its physicochemical characteristics were investigated with the use of X-ray diffraction (XRD), scanning electron microscopy (SEM), and $\mathrm{N}_{2}$ physical adsorption (BET). The performance of LNO towards SPS activation was examined for SMX degradation in ultrapure water (UPW). SMX, belonging to the group of antibiotics, has been detected in treated effluents at concentrations between $\mathrm{ng} / \mathrm{L}$ and $\mathrm{mg} / \mathrm{L}$ [32], thus proving the inadequacy of conventional water treatment methods for its degradation [33]. This phenomenon is closely related not only to adverse ecotoxicological effects but also to the development of antibacterial resistant genes posing serious threats to human health [34].

The effects of several experimental parameters, such as LNO, SMX, and SPS concentration, were investigated. Additional experiments altering initial $\mathrm{pH}$ were also carried out. Special emphasis was given to the water matrix effect, presenting results in real and synthetic water matrices. The reusability of LNO, as well as possible reaction mechanism, are also discussed.

\section{Results}

\subsection{Characterization of $L N O$}

The X RD spectrum of LNO is presented in Figure 1A. All diffraction peaks can be indexed to rhombohedral $\mathrm{LaNiO}_{3}$ (JCPDS No 341028), demonstrating the formation of the perovskite structure. The primary crystallite size of LNO, as calculated by means of Scherrer equation, is $14 \mathrm{~nm}$. Figure 1B and $1 C$ respectively show a representative SEM and TEM image of LNO. Figure $1 C$ reveals a uniform texture of spherical particles. The particle sizes are in nanoscale which is in consistent with the crystallite sizes calculated by Scherrer equation.
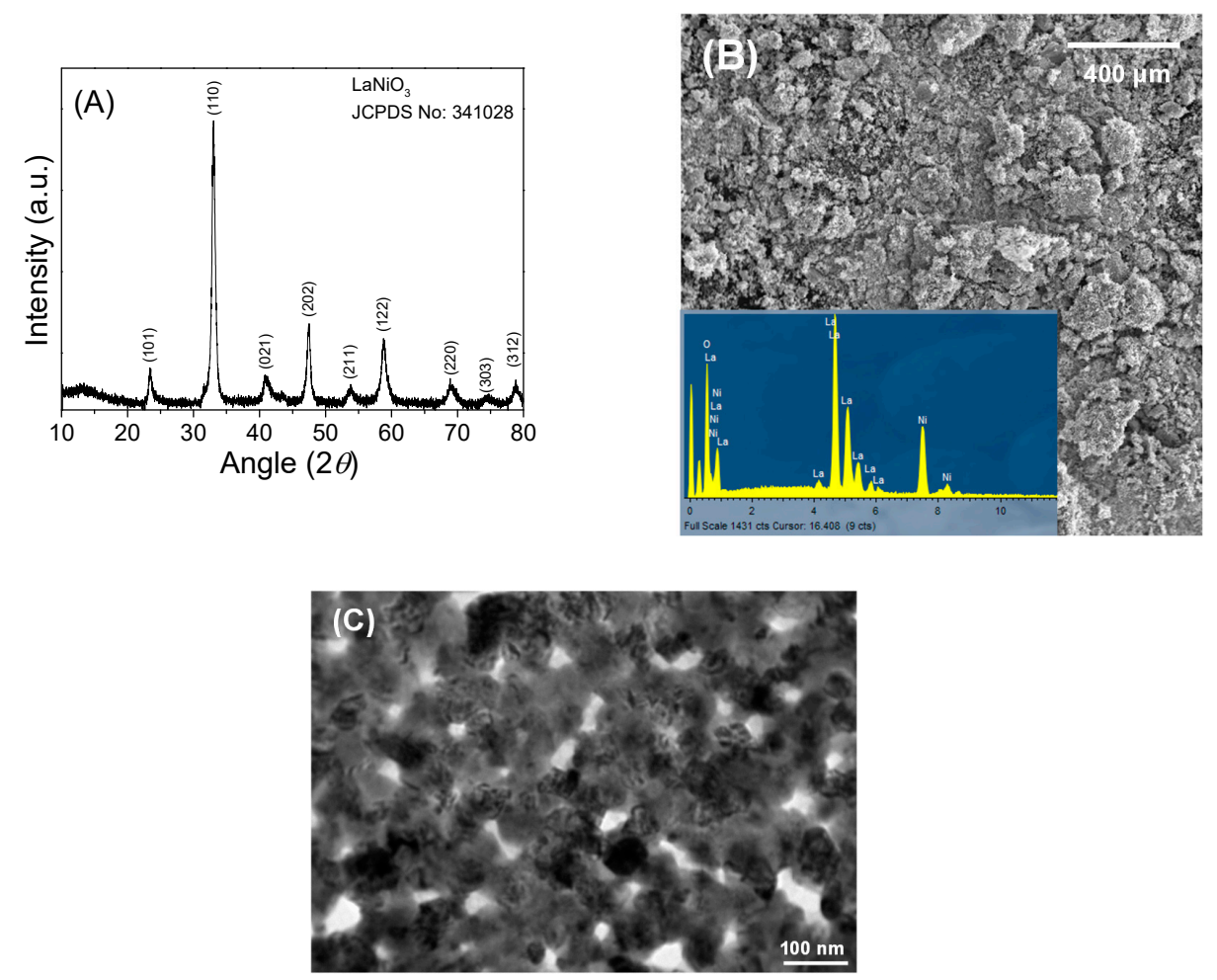

Figure 1. (A) X-ray diffraction pattern, (B) SEM image with energy dispersive spectrometer (EDS) spectrum and (C) TEM image of $\mathrm{LaNiO}_{3}(\mathrm{LNO})$. 
Zeta potential measurements (Figure 2) revealed that the LNO surface is more negatively charged at $\mathrm{pH}>10$. It should be noted that measurements obtained under acidic conditions cannot be considered trustworthy due to catalyst dissolution $[15,19,20]$. The specific surface area of LNO was found equal to $\sim 5 \mathrm{~m}^{2} / \mathrm{g}$, characteristic of as-prepared perovskite materials [15,35].

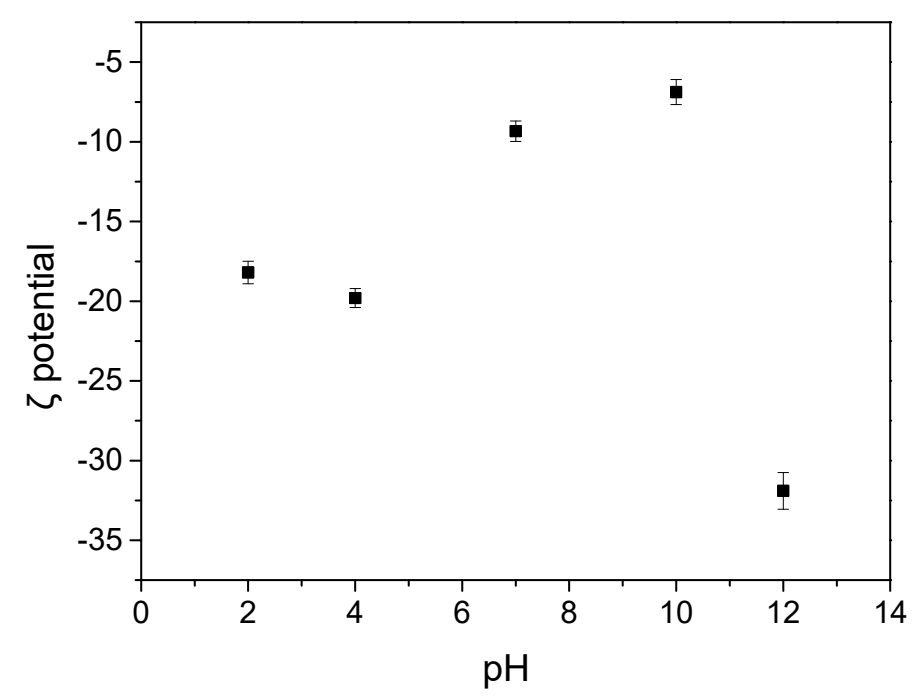

Figure 2. Zeta potential of $\mathrm{LNO}$ as a function of $\mathrm{pH}$.

\subsection{SPS Activation}

The effect of LNO, SPS, and SMX concentration on SMX degradation was examined and the results are presented in Figure 3. Figure 3A shows that 65\% SMX removal was achieved after 25 min using only $25 \mathrm{mg} / \mathrm{L}$ LNO, proving its ability to effectively activate SPS for SMX degradation. An increase in catalyst dosage enhanced SMX degradation (Figure 3A); complete SMX removal occurs after 25, 15, and $10 \mathrm{~min}$ of reaction using 50,100, and $250 \mathrm{mg} / \mathrm{L}$, respectively, in the presence of $100 \mathrm{mg} / \mathrm{L}$ SPS. The plot of $-\operatorname{Ln}\left(C / C_{0}\right)$ versus time in all tests resulted in a straight line (Figure S1) with the linear regression coefficient, $\mathrm{R}^{2}$, greater than 0.90 , indicating that these experimental data fit well to the pseudo-first-order kinetic model (Equation (1)). The computed apparent rate constants decreased as follows: $0.2267 \mathrm{~min}^{-1}$ $\left(\mathrm{C}_{\mathrm{LNO}} 250 \mathrm{mg} / \mathrm{L}\right)>0.1319 \mathrm{~min}^{-1}\left(\mathrm{C}_{\mathrm{LNO}}=100 \mathrm{mg} / \mathrm{L}\right)>0.1247 \mathrm{~min}^{-1}\left(\mathrm{C}_{\mathrm{LNO}}=50 \mathrm{mg} / \mathrm{L}\right)>0.0400 \mathrm{~min}^{-1}$ $\left(\mathrm{C}_{\mathrm{LNO}}=25 \mathrm{mg} / \mathrm{L}\right)$. This observation is in accordance with other studies, since an increase in catalyst dosage produces more active surface sites that are available for SPS activation and SMX adsorption, thus favoring pollutant degradation $[15,19,20,36,37]$. In the absence of SPS, the adsorption capacity of SMX onto the catalyst surface was negligible (ca. 10\%). Additionally, the presence of $100 \mathrm{mg} / \mathrm{L}$ SPS alone (without catalyst) showed that SPS oxidative ability was insufficient for SMX degradation (Figure 3A). 

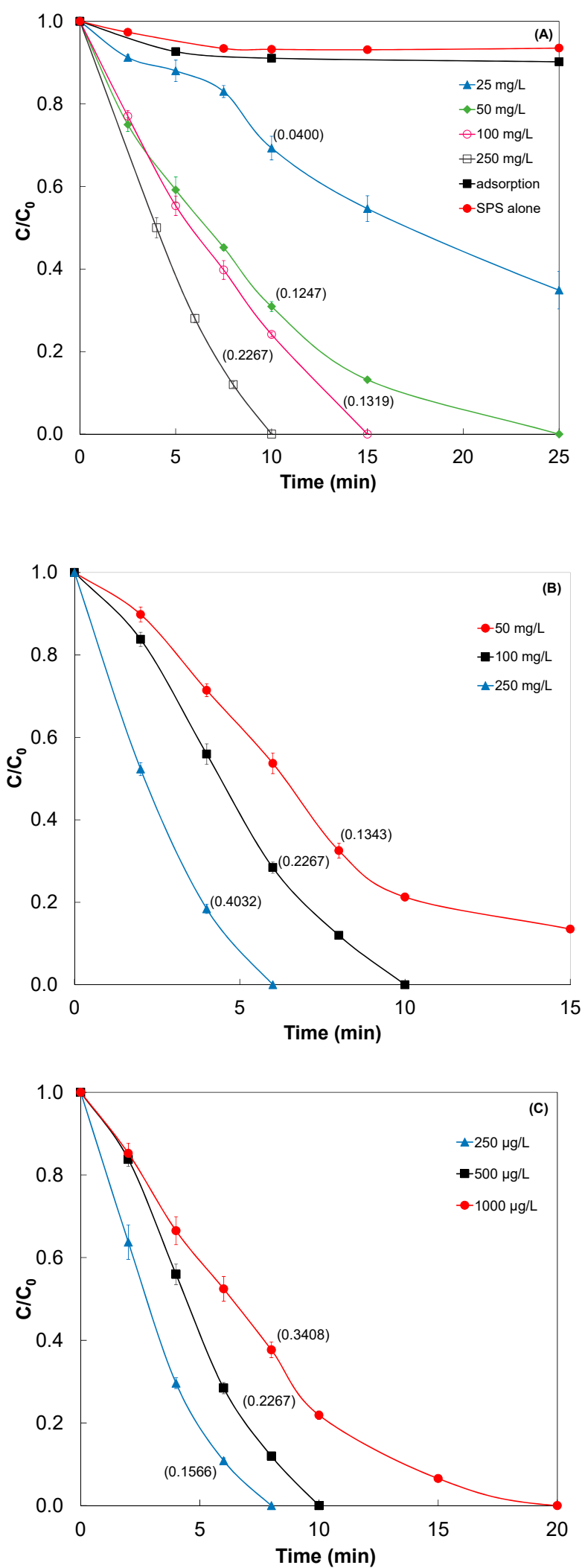

Figure 3. (A) Effect of LNO, (B) sodium persulfate (SPS) and (C) sulfamethoxazole (SMX) concentration on SMX degradation in $\mathrm{LaNiO}_{3} / \mathrm{SPS}$ system. Experimental conditions: $\mathrm{C}_{\mathrm{SMX}}=500 \mu \mathrm{g} / \mathrm{L}$ for a and b; $\mathrm{C}_{\mathrm{LNO}}=250 \mathrm{mg} / \mathrm{L}$ for $\mathrm{b}$ and $\mathrm{c} ; \mathrm{C}_{\mathrm{SPS}}=100 \mathrm{mg} / \mathrm{L}$ for $\mathrm{a}$ and $\mathrm{c} ; \mathrm{pH}=6$; room temperature. Numbers next to lines show apparent rate constants $\left(\mathrm{k}\right.$ in $\left.\mathrm{min}^{-1}\right)$. 
Figure 3B depicts the effect of the initial SPS concentration on SMX degradation. The results demonstrate that an increase in SPS concentration from 50 to $250 \mathrm{mg} / \mathrm{L}$ leads to a progressive enhancement in SMX removal, probably because more reactive species can participate in SMX degradation. For example, at 6 min of treatment time, 46\%, 72\%, and 100\% SMX degradation was observed for 50,100, and $250 \mathrm{mg} / \mathrm{L}$ initial SPS concentration, respectively. The computed rate constants were $0.1343 \mathrm{~min}^{-1}$ at $50 \mathrm{mg} / \mathrm{L}, 0.2267 \mathrm{~min}^{-1}$ at $100 \mathrm{mg} / \mathrm{L}$ and $0.4032 \mathrm{~min}^{-1}$ at $250 \mathrm{mg} / \mathrm{L}$. Considering both the economic aspects and complete SMX removal, a LNO dosage of $250 \mathrm{mg} / \mathrm{L}$ and $100 \mathrm{mg} / \mathrm{L} \mathrm{SPS}$ were applied in the following experiments.

The performance of the LNO/SPS system as a function of SMX concentration is given in Figure 3C. The removal of SMX distinctly decelerates as the pollutant concentration increases (within a range of 250 to $1000 \mathrm{mg} / \mathrm{L}$ ). Furthermore, the corresponding rate constants were $0.3408 \mathrm{~min}^{-1}, 0.2267 \mathrm{~min}^{-1}$ and $0.1566 \mathrm{~min}^{-1}$ at an initial SMX concentration of 250,500, and $1000 \mathrm{mg} / \mathrm{L}$, respectively. The increased competition between the intermediates and SMX for reactive species and catalyst surface, at a higher initial concentration of SMX, decreased the apparent $\mathrm{k}$ values. This observation is a well-known phenomenon occurring in different heterogeneous AOPs. Thus, comparable results have been reported in several previous studies $[15,38-40]$, indicating that the oxidation rate could be significantly affected by a change in the initial concentration of pollutants.

In order to obtain an insight into the efficacy of the present system towards SMX degradation, Table 1 summarizes the main characteristics of other heterogeneously activated persulfate systems employed for SMX degradation. Magioglou et al. [6], who studied the degradation of $0.5 \mathrm{mg} / \mathrm{L} \mathrm{SMX} \mathrm{by}$ biochar-activated persulfate, reported significantly longer time periods for complete SMX degradation than those reported in Figure 3. Alexopoulou et al. [14] used $\mathrm{Cu}_{3} \mathrm{P}$ as a heterogeneous persulfate activator. They found that fast degradation of SMX occurred in UPW with the rate depending on parameters such as SMX, SPS and catalyst concentrations. Their results are of the same order of magnitude as the present study. Moreover, Gkika et al. [15] studied the heterogeneous activation of SPS by $\mathrm{La}_{0.8} \mathrm{Sr}_{0.2} \mathrm{CoO}_{3-\delta}$, reporting $\mathrm{k}$ values between 0.022 and $0.061 \mathrm{~min}^{-1}$ (depending on the catalyst dosage) for the degradation of $0.5 \mathrm{mg} / \mathrm{L} \mathrm{SMX}$ with $500 \mathrm{mg} / \mathrm{L} \mathrm{SPS}$. In another study, Fe(II)-based metal-organic frameworks (MOFs) were synthesized for the degradation of SMX [41]. The results showed that $500 \mathrm{mg} / \mathrm{L} \mathrm{Fe}(\mathrm{II}) \mathrm{MOF}$ could effectively activate $500 \mathrm{mg} / \mathrm{L}$ persulfate leading to $\sim 97 \%$ removal of $10 \mathrm{mg} / \mathrm{L} \mathrm{SMX}$ in $180 \mathrm{~min}$, with a $\mathrm{k}$ value equal to $0.056 \mathrm{~min}^{-1}$, lower than the present study. Wu et al. studied the heterogeneous activation of persulfate using $\mathrm{Fe}_{3} \mathrm{O}_{4}$ nanoparticles [42], showing promising results in the application of $\mathrm{Fe}_{3} \mathrm{O}_{4}$ in water decontamination systems. The effect of several experimental parameters, as well as the water matrix effect were thoroughly analyzed in their study [42]. They observed that the rate constant increased from $8.07 \pm 0.58 \times 10^{-5} \mathrm{~s}^{-1}$ to $1.11 \pm 0.10 \times 10^{-4} \mathrm{~s}^{-1}$, increasing $\mathrm{Fe}_{3} \mathrm{O}_{4}$ concentration from 0.3 to $1.0 \mathrm{~g} / \mathrm{L}$, while further increase to $2.0 \mathrm{~g} / \mathrm{L}$ inhibited SMX degradation [42]. Moreover, SMX degradation efficiency decreased with increasing $\mathrm{pH}$ value, while chloride ions hindered SMX degradation at $\mathrm{pH}$ 4.0, but had no impact on SMX degradation at $\mathrm{pH} 10.5$ [42]. Magnetic graphitized biochar (GMBC) synthesized from pine wood-derived biochar has been also proposed as heterogeneous catalyst for persulfate activation showing good performance for complete SMX removal from water [43]. In this case, almost $100 \%$ degradation of $10 \mathrm{mg} / \mathrm{L} \mathrm{SMX}$ was recorded within $60 \mathrm{~min}$, with the corresponding $\mathrm{k}$ value equal to $0.179 \mathrm{~min}^{-1}[43]$. 
Table 1. SMX degradation in different heterogeneous activated persulfate systems. N.G.: not given.

\begin{tabular}{|c|c|c|c|c|c|c|}
\hline Catalyst & $\begin{array}{c}\text { SMX } \\
\text { Concentration } \\
(\mathrm{mg} / \mathrm{L})\end{array}$ & $\begin{array}{c}\text { Catalyst } \\
\text { Concentration } \\
(\mathrm{mg} / \mathrm{L})\end{array}$ & $\begin{array}{c}\text { Persulfate } \\
\text { Concentration } \\
(\mathrm{mg} / \mathrm{L})\end{array}$ & $\begin{array}{c}\mathbf{k} \\
\left(\min ^{-1}\right)\end{array}$ & $\begin{array}{c}\text { Time Period for } \\
\text { Complete Degradation } \\
\text { (min) }\end{array}$ & Ref. \\
\hline Biochar & 0.5 & 200 & 1000 & 0.013 & N.G. & [6] \\
\hline $\mathrm{Cu}_{3} \mathrm{P}$ & 0.5 & 40 & 100 & 0.114 & 20 & [14] \\
\hline $\mathrm{La}_{0.8} \mathrm{Sr}_{0.2} \mathrm{CoO}_{3-\delta}$ & 0.5 & 500 & 500 & 0.054 & 45 & [15] \\
\hline $\mathrm{Fe}(\mathrm{II}) \mathrm{MOFs}$ & 10 & 500 & 500 & 0.056 & 180 & [41] \\
\hline $\mathrm{Fe}_{3} \mathrm{O}_{4}$ & 0.3 & 1000 & 350 & 0.008 & N.G. & [42] \\
\hline GMBC & 10 & 200 & 710 & 0.179 & 60 & [43] \\
\hline $\mathrm{Bi}_{2} \mathrm{Fe}_{4} \mathrm{O}_{9}$ & 5 & 100 & 60 & 0.140 & 30 & [44] \\
\hline $\mathrm{CoFe}_{2} \mathrm{O}_{4} / \mathrm{Al}_{2} \mathrm{O}_{3}$ & 10 & N.G. & 100 & N.G. & 60 & [45] \\
\hline FeZn@NC & 5 & 100 & 240 & 0.080 & 80 & [46] \\
\hline Biochar/Fe(III) & 10 & 500 & 500 & 0.019 & 90 & [47] \\
\hline LNO & 0.5 & 250 & 100 & 0.226 & 10 & This study \\
\hline
\end{tabular}

Bismuth ferrite $\left(\mathrm{Bi}_{2} \mathrm{Fe}_{4} \mathrm{O}_{9}\right)$ is another metal oxide, proposed as a heterogeneous activator for SMX removal [44]. Specifically, Oh et al. found that the mixed metal system had greater stability and activity than single metal systems $\left(\mathrm{Co}_{3} \mathrm{O}_{4}\right.$ and $\left.\mathrm{Fe}_{2} \mathrm{O}_{3}\right)$ with $5 \mathrm{mg} / \mathrm{L} \mathrm{SMX}$ being degraded in $30 \mathrm{~min}$ using $60 \mathrm{mg} / \mathrm{L}$ sodium persulfate [44]. High efficiency towards persulfate activation was also achieved using $\mathrm{CoFe}_{2} \mathrm{O}_{4}$ mixed oxide immobilized on $\mathrm{Al}_{2} \mathrm{O}_{3}$ ceramic membrane [45]. In this case, $10 \mathrm{mg} / \mathrm{L} \mathrm{SMX}$ was degraded after $60 \mathrm{~min}$ [44]. In an attempt to enhance the activity of carbon materials towards persulfate activation, Yanan et al. synthesized carbon nanotubes (NCNTs) encapsulating Zn and Fe hybrid metal particles (FeZn@NC), and tested them for SMX degradation [46]. They observed that an almost complete removal of $5 \mathrm{mg} / \mathrm{L} \mathrm{SMX}$ took place after $90 \mathrm{~min}$, with the degradation rate being highly dependent on the mass ratio of zinc to iron in the FeZn@NC nanoparticles [46]. The maximum $k$ value was $0.082 \mathrm{~min}^{-1}$, i.e., an order of magnitude lower than that reported in Figure 3. The authors paid special attention to the reactive oxygen species produced through persulfate activation, suggesting that ${ }^{1} \mathrm{O}_{2}$ was the main species in the FeZn@NC/PS system for SMX degradation [46]. Another significant contribution to the enlightenment of persulfate activation mechanism was made by Wang et al. [47] studying the biochar-induced Fe(III) reduction for SMX degradation. They pointed out that persistent free radicals contained in biochars and other pyrogenic carbonaceous materials play a key role in these degradation processes. A value of $0.019 \mathrm{~min}^{-1}$ was recorded for the degradation of $10 \mathrm{mg} / \mathrm{L} \mathrm{SMX}$ with $500 \mathrm{mg} / \mathrm{L}$ biochar and $500 \mathrm{mg} / \mathrm{L}$ SPS.

Comparing the results of the present work to previous studies of our group [6,14,15], it is evident that LNO is more effective than other materials for SMX degradation. Moreover, comparing the efficiency of the most studied $\mathrm{Co}, \mathrm{Fe}, \mathrm{Cu}$-based oxides, as well as carbon-based materials with the marginally studied Ni-based perovskite oxide proposed by the present study, it is observed that Ni-based materials show great potential towards persulfate activation, thus deserving further investigation.

In other studies on the heterogeneous activation of persulfate for micropollutant degradation, the time period for complete degradation varied depending on SPS or catalyst dosage. Characteristic examples are summarized in Table 2. $\mathrm{MnO}_{\mathrm{x}}$ loaded on ordered mesoporous carbon composites $\left(\mathrm{MnO}_{\mathrm{x}} @ \mathrm{OMC}\right)$ was found effective for phenol degradation by persulfate activation [10]. Lei et al. [13] stated that almost $100 \%$ mineralization of $0.1 \mathrm{mM}$ phenol could be achieved in 120 min using $0.3 \mathrm{~g} / \mathrm{L}$ $\mathrm{CuO}-\mathrm{Fe}_{3} \mathrm{O}_{4}$ and $5.0 \mathrm{mM}$ SPS at pH 11.0, while Miao et al. [20] demonstrated that $\mathrm{SrCo}_{1-x} \mathrm{Ti}_{x} \mathrm{O}_{3-\delta}$ exhibited a fast catalytic activity for phenol oxidation in the presence of peroxymonosulfate in a wide $\mathrm{pH}$ range. Jiang et al. [22] showed that the addition of reduced graphene oxide (RGO) effectively prevented agglomeration of $\mathrm{Ni}_{2} \mathrm{SnO}_{4}$ nanoparticles and improved its catalytic performance towards SPS activation to degrade bisphenol A. 
Table 2. Persulfate activation by heterogeneous systems. N.G.: not given.

\begin{tabular}{ccccccc}
\hline Catalyst & Micro-Pollutant & $\begin{array}{c}\text { Catalyst } \\
\text { Concentration } \\
\mathbf{( m g} / \mathbf{L})\end{array}$ & $\begin{array}{c}\text { Persulfate } \\
\text { Concentration } \\
\mathbf{( m M )}\end{array}$ & $\begin{array}{c}\mathbf{k} \\
\left(\mathbf{m i n}^{-\mathbf{1}}\right)\end{array}$ & $\begin{array}{c}\text { Time Period for } \\
\text { Complete Degradation } \\
\text { (min) }\end{array}$ & Ref. \\
\hline $\mathrm{MnO}_{\mathbf{x}} @ \mathrm{OMC}$ & Phenol & 20 & 1.0 & 0.143 & 3 & {$[10]$} \\
$\mathrm{CuO} / \mathrm{Fe}_{3} \mathrm{O}_{4}$ & Phenol & 9.4 & 5.0 & N.G. & 120 & {$[13]$} \\
$\mathrm{SrCo}_{1-\mathrm{x}} \mathrm{Ti}_{\mathrm{x}} \mathrm{O}_{3-\delta}$ & Phenol & 20 & 13 & 0.056 & 20 & {$[20]$} \\
$\mathrm{Ni}_{2} \mathrm{SnO}_{4}-\mathrm{RGO}$ & Bisphenol A & 23 & 20 & 0.063 & 50 & {$[22]$} \\
\hline
\end{tabular}

\section{3. $p H$ Effect}

The effect of medium $\mathrm{pH}$ is a well-known factor for the degradation of organic pollutants. Therefore, the impact of two initial $\mathrm{pH}$ values $(6.0,9.0)$ on SMX degradation was studied in the LNO/SPS system, and the results are depicted in Figure 4. It should be noted that the buffer solution was not used to constrain any potential interferences of buffering agents; however, $\mathrm{pH}$ values did not change throughout the course of the reaction. As seen, the LNO/SPS system is effective at near-neutral $\mathrm{pH}$, leading to complete removal of SMX within $10 \mathrm{~min}$. An increase of the $\mathrm{pH}$ value to 9 led to a total inhibition of SMX removal, implying that basic conditions change the surface of perovskite oxide and the target compound's physicochemical properties. Indeed, SMX has two $\mathrm{pK}_{\mathrm{a}}$ values $\left(\mathrm{pK}_{\mathrm{a}, 1}=1.85 \pm 0.30\right.$ and $\left.\mathrm{pK}_{\mathrm{a}, 2}=5.60 \pm 0.04\right)$ [48], suggesting that it is positively charged at $\mathrm{pH}<\mathrm{pK}_{\mathrm{a}, 1}$, not charged at $\mathrm{pK}_{\mathrm{a}, 1}<\mathrm{pH}<\mathrm{pK}_{\mathrm{a}, 2}$ and negatively charged at $\mathrm{pH}>\mathrm{pK}_{\mathrm{a}, 2}$. Moreover and according to zeta potential measurements (Figure 2), LNO is negatively charged at basic $\mathrm{pH}$, resulting in repulsive forces between the catalyst surface and SMX. An additional experiment was performed at acidic conditions $(\mathrm{pH}=3)$ resulting in severe LNO dissolution (data not shown). Similar results regarding the instability of perovskite materials at acidic environments have been reported elsewhere $[15,19,20]$.

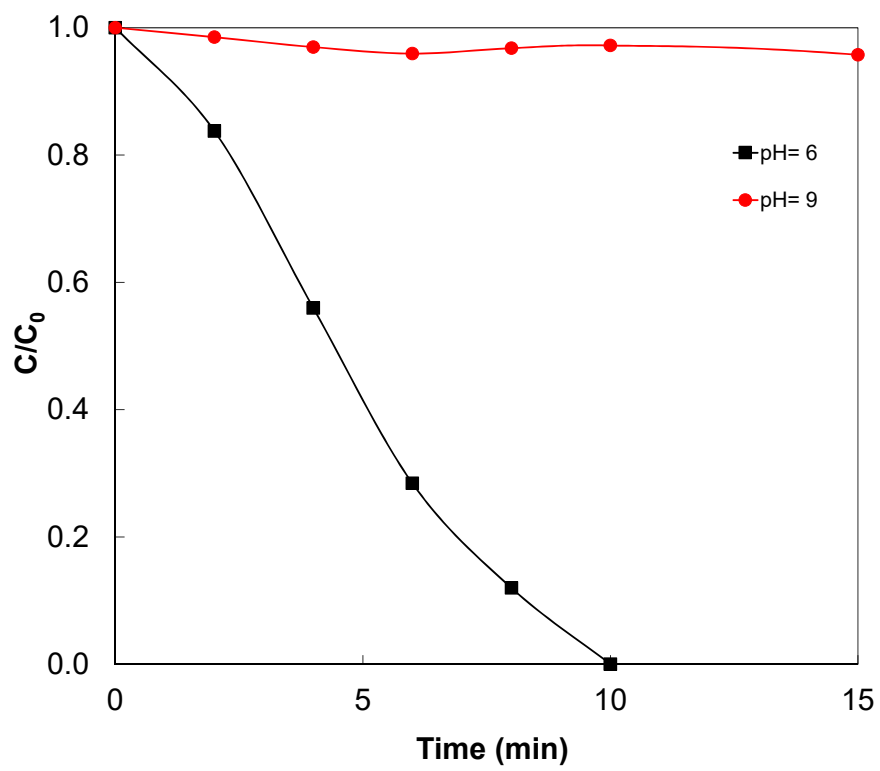

Figure 4. Effect of initial $\mathrm{pH}$ on SMX degradation in LNO/SPS system. Experimental conditions: $\mathrm{C}_{\mathrm{SMX}}=500 \mu \mathrm{g} / \mathrm{L} ; \mathrm{C}_{\mathrm{LNO}}=250 \mathrm{mg} / \mathrm{L} ; \mathrm{C}_{\mathrm{SPS}}=100 \mathrm{mg} / \mathrm{L} ;$ room temperature.

\subsection{Applicability of $\mathrm{LaNiO}_{3} / \mathrm{SPS}$ System for the Degradation of Various Micro-Pollutants}

The LNO/SPS system performance in eliminating other organic pollutants commonly detected in the aquatic environment was additionally evaluated. Therefore, experiments were carried out to degrade $500 \mu \mathrm{g} / \mathrm{L}$ of piroxicam (PIR) or methylparaben (MeP). These compounds have been recently classified as emerging pollutants by the US Environmental Protection Agency [49,50]. However, they are still widely used in several applications; MeP is employed as a preservative in foodstuff, 
cosmetics, and personal care products [49], while PIR is used mainly as a painkiller in order to decrease fever and to prevent blood clots [50]. As seen in Figure 5, PIR was rapidly degraded in less than 2 min, while $\mathrm{MeP}$ was eliminated within $10 \mathrm{~min}$. The satisfactory degradation of several other micropollutants suggests a robust catalytic performance of the applied system.

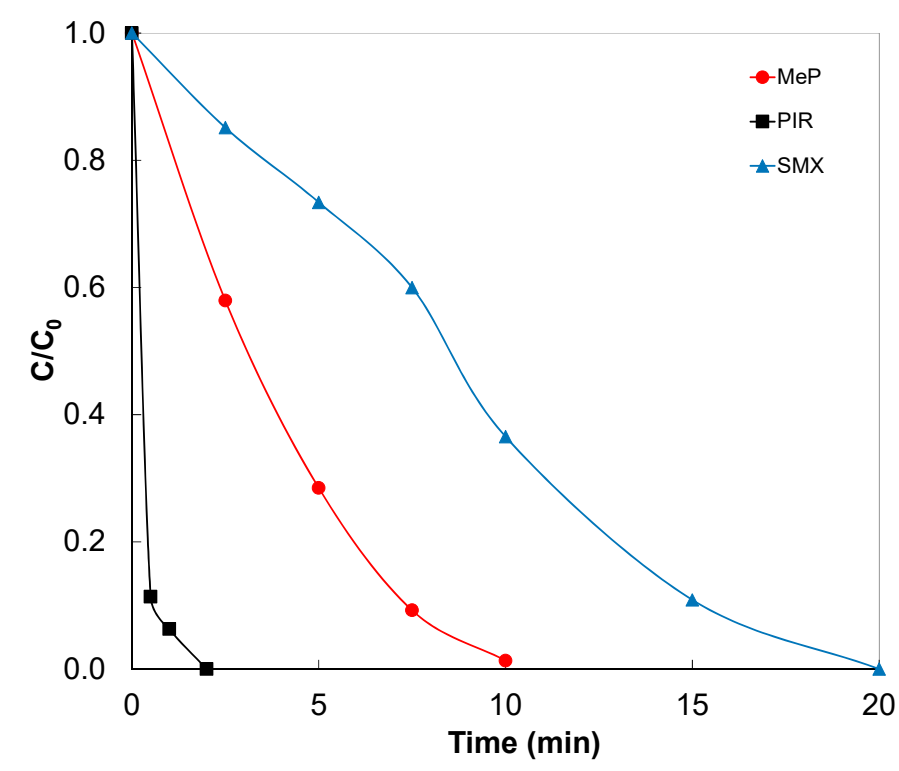

Figure 5. Effect of type of micropollutant on degradation efficiency of methyl paraben (MeP), piroxicam (PIR) and SMX in LNO/SPS system. Experimental conditions: $\mathrm{C}_{\text {compound }}=500 \mu \mathrm{g} / \mathrm{L} ; \mathrm{C}_{\mathrm{LNO}}=250 \mathrm{mg} / \mathrm{L}$; $\mathrm{C}_{\mathrm{SPS}}=100 \mathrm{mg} / \mathrm{L} ; \mathrm{pH}=6$; room temperature.

\subsection{Water Matrix Effect}

To further assess the applicability of the LNO/SPS system, its activity in different water matrices was investigated. A set of experiments were carried out in wastewater (WW), wastewater diluted with an equal volume of UPW (50\% WW), and bottled water (BW), and the results are depicted in Figure 6. It is observed that the presence of various organic and inorganic substances in actual water matrices (see Table S1) dramatically affects degradation leading to less than $25 \%$ SMX removal after 15 min. Apart from the complexity of these matrices, their slightly alkaline nature could significantly affect SMX removal, as has already been discussed in Section 2.3 (see Figure 4). For this reason, the experiment in WW was repeated after having adjusted its initial $\mathrm{pH}$ value of 8 (Table S1) to 6. As seen in Figure 6, no evident change was recorded. A similar adverse effect of real water matrices, e.g., wastewater, tap water, and river water, on the degradation rate of various pollutants using perovskite materials for SPS activation has also been reported elsewhere $[4,15]$. 


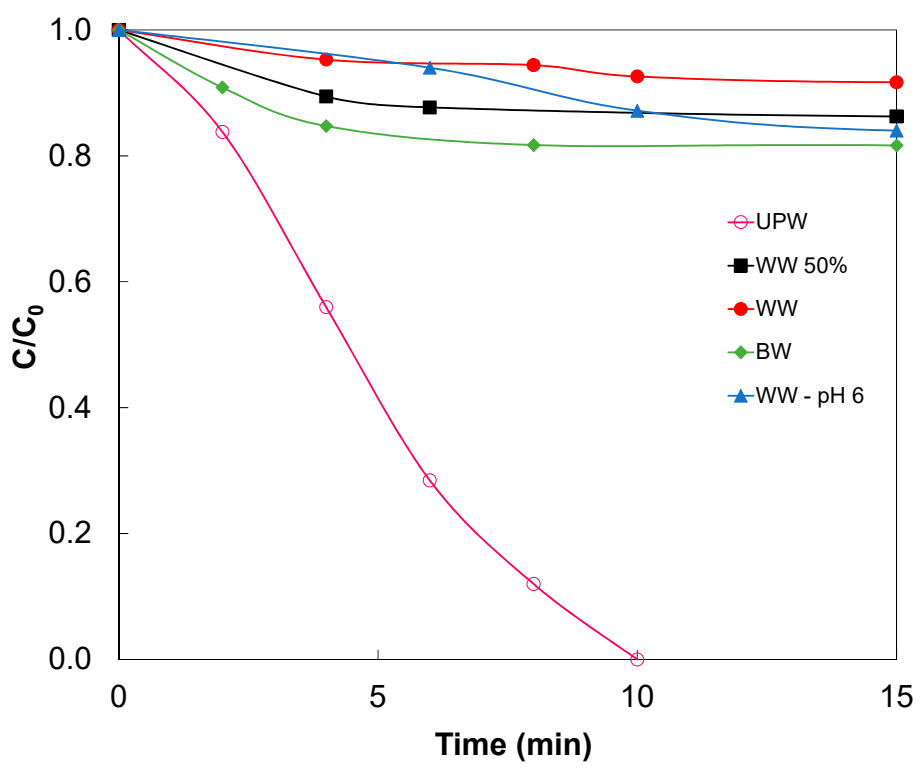

Figure 6. Effect of water matrix on SMX degradation. Experimental conditions: $\mathrm{C}_{\mathrm{SMX}}=500 \mu \mathrm{g} / \mathrm{L}$; $\mathrm{C}_{\mathrm{LNO}}=250 \mathrm{mg} / \mathrm{L} ; \mathrm{C}_{\mathrm{SPS}}=100 \mathrm{mg} / \mathrm{L}$; room temperature.

The effect of natural organic matter and inorganic anions such as $\mathrm{HCO}_{3}^{-}$and $\mathrm{Cl}^{-}$on SMX degradation in the LNO/SPS system was investigated (Figure 7) [51]. As seen, the addition of $\mathrm{HCO}_{3}^{-}$in the system had a detrimental influence on SMX degradation at both concentration levels tested (i.e., 125 and $250 \mathrm{mg} / \mathrm{L}$ which are typical of those found in BW and WW-see Table S1); on the other hand, the addition of $250 \mathrm{mg} / \mathrm{L} \mathrm{Cl}^{-}$did not practically affect SMX degradation. These results could be attributed to the possible formation of radicals with lower redox potentials. For instance, $\mathrm{HCO}_{3}^{-} \mathrm{can}$ rapidly be transformed to $\mathrm{CO}_{3}{ }^{2-}$, both of which can eventually react with sulfate and hydroxyl radicals, forming carbonate radicals $\left(\mathrm{HCO}_{3}{ }^{\bullet}\right.$ and $\left.\mathrm{CO}_{3}{ }^{--}\right)$of lower oxidation potential [15,36,52]. Sulfate and hydroxyl radicals can also react with $\mathrm{Cl}^{-}$forming $\mathrm{Cl}^{\bullet}$ which can further react with chloride forming $\mathrm{Cl}_{2}{ }^{\bullet-}$. Consequently, these radicals $\mathrm{Cl}^{\bullet}, \mathrm{Cl}_{2}{ }^{\bullet-}$ are likely to contribute to the degradation of the target compound $[15,52,53]$. According to previous studies concerning the use of perovskite materials for SPS activation, diverse results have been reported about the effect of common inorganic anions, e.g., $\mathrm{HCO}_{3}^{-}$and $\mathrm{Cl}^{-}$, on pollutant degradation. Lin et al. [53] reported that the presence of $\mathrm{NaCl}$ from 250 to $1000 \mathrm{mg} / \mathrm{L}$ noticeably decreased the degradation kinetics of dyes in the presence of $\mathrm{LaMO}_{3}$. Comparable results were obtained using $\mathrm{CaMnO}_{3}, \mathrm{La}_{0.8} \mathrm{Sr}_{0.2} \mathrm{CoO}_{3-\delta}$ and $\mathrm{LaCoO}_{3}$ nanocomposites as persulfate activators for the removal of phenol and pharmaceutical compounds [15,36,51]. A 4-fold decrease was observed in the rate constant of ciprofloxacin degradation when $20 \mathrm{mmol} / \mathrm{L} \mathrm{Cl}^{-}$were added in water in the presence of Sr-doped $\mathrm{BiFeO}_{3}$ [54]. The detrimental effect of bicarbonate on the degradation of SMX and phenol with persulfate was reported when SPS was activated with $\mathrm{La}_{0.8} \mathrm{Sr}_{0.2} \mathrm{CoO}_{3-\delta}$ and $\mathrm{CaMnO}_{3}$, respectively [15,36]. Guo et al. [51] observed that the presence of bicarbonate could significantly retard carbamazepine oxidation in the $\mathrm{LaCoO}_{3} / \mathrm{SPS}$ system. Wang et al. [54] also reported a negative effect on ciprofloxacin degradation in the $\mathrm{BiFeO}_{3} / \mathrm{SPS}$ system with the addition of $\mathrm{HCO}_{3}^{-}$. 


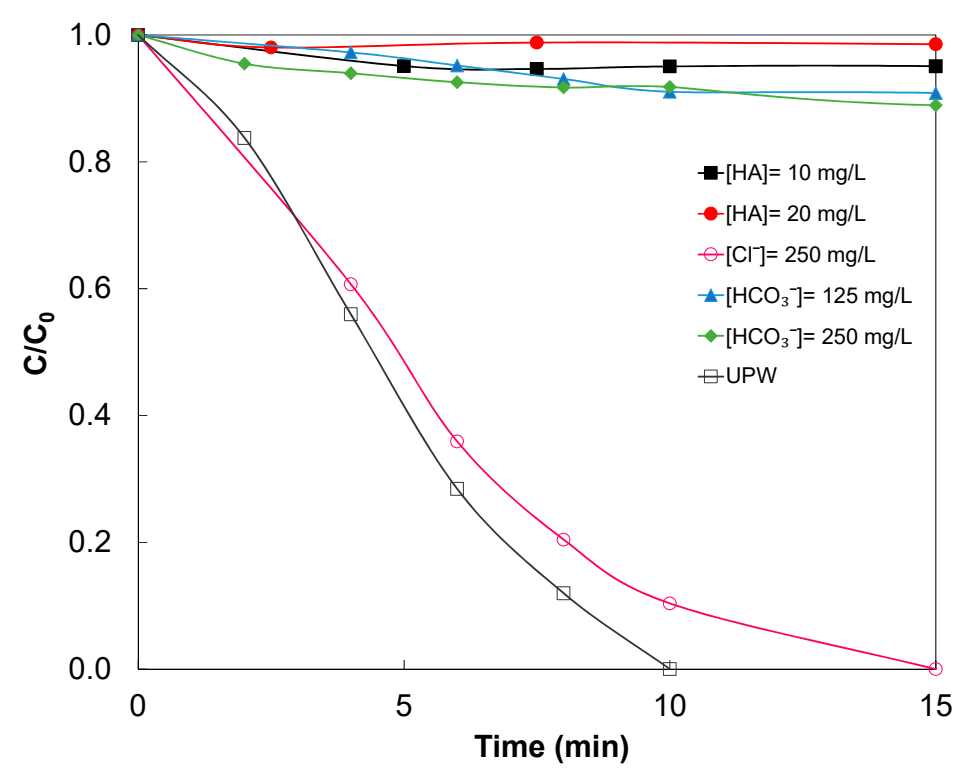

Figure 7. Effect of organic matter and inorganic anions at various concentrations, on SMX degradation. Experimental conditions: $\mathrm{C}_{\mathrm{SMX}}=500 \mu \mathrm{g} / \mathrm{L} ; \mathrm{C}_{\mathrm{LNO}}=250 \mathrm{mg} / \mathrm{L} ; \mathrm{C}_{\mathrm{SPS}}=100 \mathrm{mg} / \mathrm{L}$; room temperature.

As can also be seen in Figure 7, the presence of humic acid (HA) at two concentrations (i.e., 10 and $20 \mathrm{mg} / \mathrm{L}$ representative of the level of total organic carbon found in WW-see Table S1) completely suppressed the SMX degradation rate. This negative result may be due to either the scavenging of reactive oxygen species by HA $[15,55,56]$ or competition for the catalyst surface. This is consistent with the reported adverse effect of HA on SMX degradation using lanthanum strontium cobaltite as catalyst for SPS activation [15]. In contrast, Guo and et al. [51] found that the presence of HA did not affect carbamazepine degradation using lanthanum cobaltite perovskite as the activator.

\subsection{Reactive Species and Catalyst Reusability}

Trapping experiments were conducted to investigate the dominant reactive species and their contributions to the present system. For this reason, tert-butyl alcohol (TBA) and methanol (MeOH) were selected as $\mathrm{OH}^{\bullet}$ and $\mathrm{SO}_{4}{ }^{\bullet-}$ scavengers. TBA is an effective $\mathrm{OH}^{\bullet}$ quenching agent $\left(\mathrm{k}_{(\mathrm{t}-\mathrm{ButOH}, \mathrm{HO}}\right)$ $\left.=6 \times 10^{8} \mathrm{M}^{-1} \mathrm{~s}^{-1}\right)$, while $\mathrm{MeOH}$ can react with both $\mathrm{OH}^{\bullet}$ and $\mathrm{SO}_{4}{ }^{\bullet-}\left[\mathrm{k}_{(\mathrm{MeOH}, \mathrm{HO} \bullet}\right)=9.7 \times 10^{8} \mathrm{M}^{-1} \mathrm{~s}^{-1}$ $\left.\mathrm{k}_{\left(\mathrm{MeOH}, \mathrm{SO}^{\circ} \bullet^{-}\right)}=1.1 \times 10^{7} \mathrm{M}^{-1} \mathrm{~s}^{-1}\right][57,58]$. As seen in Figure 8, a high dosage of each scavenger relative to the SPS concentration (TBA:SPS $=\mathrm{MeOH}: \mathrm{SPS}=100: 1$ ) resulted in different inhibitory effects on $500 \mu \mathrm{g} / \mathrm{L}$ SMX degradation. More specifically, SMX degradation was substantially decreased to nearly $50 \%$ after $10 \mathrm{~min}$, in the presence of either TBA or MeOH. However, complete SMX degradation was achieved in the case of TBA at the end of the 25 -min long experiment, while only $70 \%$ removal was recorded in the case of $\mathrm{MeOH}$. This indicates that both $\mathrm{OH}^{\bullet}$ and $\mathrm{SO}_{4}{ }^{\bullet-}$ were generated in the LNO/SPS system, with $\mathrm{SO}_{4}{ }^{--}$being the primary radical species. Numerous studies on persulfate activation with perovskite oxides also reported that oxidation reactions were mainly driven by $\mathrm{SO}_{4}{ }^{\bullet-}$ and, to a lesser extent, by $\mathrm{OH}^{\bullet}[15,17,19,21,36,37,51,53,59,60]$. 


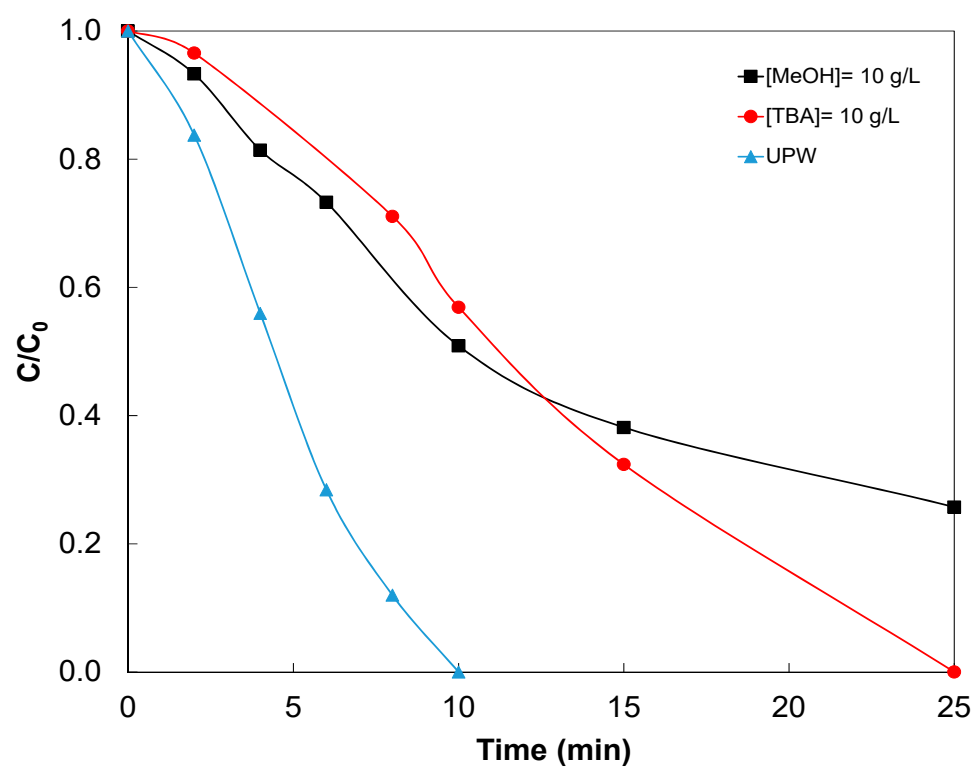

Figure 8. Effect of radical scavengers on SMX degradation. Experimental conditions: $\mathrm{C}_{\mathrm{SMX}}=500 \mu \mathrm{g} / \mathrm{L}$; $\mathrm{C}_{\mathrm{LNO}}=250 \mathrm{mg} / \mathrm{L} ; \mathrm{C}_{\mathrm{SPS}}=100 \mathrm{mg} / \mathrm{L} ; \mathrm{pH}=6$; room temperature.

In the final set of experiments, the recyclability and reusability of LNO was tested in four consecutive cycles. As seen in Figure 9, LNO retained its activity leading to complete SMX degradation within the same period of time. These results indicate that $\mathrm{LaNiO}_{3}$ can be a promising heterogeneous SPS activator for the treatment of SMX-containing wastewater in real life applications.

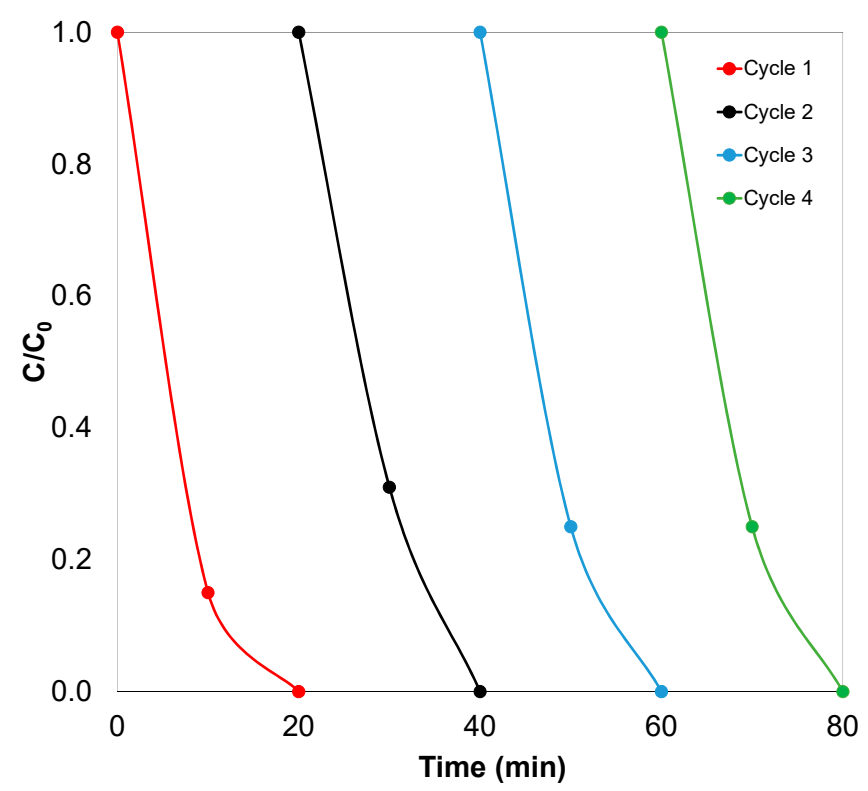

Figure 9. Removal of SMX for four consecutive runs. Experimental conditions: $\mathrm{C}_{\mathrm{SMX}}=500 \mu \mathrm{g} / \mathrm{L}$; $\mathrm{C}_{\mathrm{LNO}}=250 \mathrm{mg} / \mathrm{L} ; \mathrm{C}_{\mathrm{SPS}}=100 \mathrm{mg} / \mathrm{L} ; \mathrm{pH}=6$; room temperature.

\section{Materials and Methods}

\subsection{Chemicals and Water Matrices}

Sulfamethoxazole $\left(\mathrm{C}_{10} \mathrm{H}_{11} \mathrm{~N}_{3} \mathrm{O}_{3} \mathrm{~S} ; \mathrm{SMX}\right)$, sodium persulfate $\left(\mathrm{Na}_{2} \mathrm{~S}_{2} \mathrm{O}_{8} ; \mathrm{SPS}\right)$, sodium bicarbonate $\left(\mathrm{NaHCO}_{3}\right)$, sodium hydroxide $(\mathrm{NaOH})$, sulfuric acid $\left(\mathrm{H}_{2} \mathrm{SO}_{4}\right)$, tert-butyl alcohol (TBA), phosphoric acid 
$\left(\mathrm{H}_{3} \mathrm{PO}_{4}\right)$, and humic acid (HA) were purchased from Sigma-Aldrich (St. Louis, MO, USA). Lanthanum (III) nitrate hexahydrate $\left(\mathrm{La}\left(\mathrm{NO}_{3}\right)_{3} \cdot 6 \mathrm{H}_{2} \mathrm{O}\right)$, nickel (II) nitrate hexahydrate $\left(\mathrm{Ni}\left(\mathrm{NO}_{3}\right)_{2} \cdot 6 \mathrm{H}_{2} \mathrm{O}\right)$, ammonium nitrate $\left(\mathrm{NH}_{4} \mathrm{NO}_{3}\right)$ citric acid $\left(\mathrm{C}_{6} \mathrm{H}_{8} \mathrm{O}_{7}\right)$, and ammonia solution $\left(\mathrm{NH}_{3}\right)$, used for catalyst preparation, were also obtained from Sigma-Aldrich Aldrich (St. Louis, MO, USA). Methanol (MeOH) and acetonitrile $(\mathrm{ACN})$, both in chromatographic grade, were supplied by Merck. All chemicals were of analytical purity and used without further purification. All aqueous solutions were prepared in ultrapure water (UPW) with a resistivity of $0.056 \mu \mathrm{S} / \mathrm{cm}$ and $\mathrm{pH}=6$, at $25^{\circ} \mathrm{C}$ from a Millipore Water Milli-Q purification system Aldrich (St. Louis, MO, USA).

Wastewater samples were collected from the wastewater treatment plant located in the University of Patras campus, Greece. Commercially bottled water was used for experiments in the drinking water matrix. Properties of the water matrices are given in Table S1.

\subsection{Catalyst Synthesis and Characterization}

For LNO preparation, appropriate amounts of $\mathrm{La}\left(\mathrm{NO}_{3}\right)_{3} \cdot 6 \mathrm{H}_{2} \mathrm{O}$, nickel (II) nitrate and $\mathrm{Ni}\left(\mathrm{NO}_{3}\right)_{2} \cdot 6 \mathrm{H}_{2} \mathrm{O}$ were dissolved in UPW. $\mathrm{NH}_{4} \mathrm{NO}_{3}\left(\mathrm{NH}_{4} \mathrm{NO}_{3}\right.$ to metal ions molar ratio 1:1) and citric acid $\mathrm{C}_{6} \mathrm{H}_{8} \mathrm{O}_{7}\left(\mathrm{C}_{6} \mathrm{H}_{8} \mathrm{O}_{7}\right.$ to metal ions molar ratio 2:1) was then added. The $\mathrm{pH}$ of the solution was adjusted to 9 with the addition of $\mathrm{NH}_{3}$. The solution was heated at $200{ }^{\circ} \mathrm{C}$, and after water evaporation, heating temperature was raised to $400^{\circ} \mathrm{C}$ with the help of a heating gun. Finally, the as-obtained powder was calcined at $700{ }^{\circ} \mathrm{C}$ for $5 \mathrm{~h}$. Details can be found elsewhere [35].

A Brucker D8 Advance ( $\mathrm{Cu} \mathrm{K} \alpha)$ device (Billerica, MA, USA) was used for XRD analysis. Crystallographic phases naming was based on JCPDS cards. Nanocrystals primary crystallite size was calculated according to Debye-Scherrer's equation [53]. Specific surface area of LNO was determined with the Brunaueur-Emmett-Teller (BET) method $\left(\mathrm{N}_{2}\right.$ physisorption at the temperature of liquid nitrogen $(77 \mathrm{~K})$ ) using a Micromeritics (Gemini III 2375, Norcross, GA, USA). Zeta potential measurements were carried out via laser doppler micro-electrophoresis with a use of a Malvern Zetasizer (Nano-ZS, Malvern, UK). SEM images were obtained with the use of a JEOL 6300 (JEOL USA, Inc.) microscope equipped with an energy dispersive spectrometer (EDS) allowing element distribution of LNO. TEM images were recorded by means of an Erlangshen CCD Camera (Gatan Model 782 ES500 W, CA, USA). The specimens were prepared by dispersion in water and spread onto a carbon-coated copper grid (200 mesh). Details about physicochemical characterization can be found elsewhere [15].

\subsection{Catalytic Degradation Experiments}

Typically, $15 \mathrm{mg}$ of catalyst were added into a $60 \mathrm{~mL}$ solution containing $500 \mu \mathrm{g} / \mathrm{L} \mathrm{SMX}$ in a $100 \mathrm{~mL}$ beaker open to the atmosphere and the mixture was stirred for $15 \mathrm{~min}$ to achieve adsorption-desorption equilibrium. Then, $100 \mathrm{mg} / \mathrm{L}$ SPS was added into the suspension to initiate the reaction under continuous magnetic stirring. Experiments were, in most cases, conducted in UPW and $\mathrm{pH}$ was adjusted with an appropriate aliquot of $\mathrm{NaOH}$ or $\mathrm{H}_{2} \mathrm{SO}_{4}$ when needed. At pre-set periods, $1.2 \mathrm{~mL}$ of aliquot was withdrawn, and immediately added $300 \mu \mathrm{L} \mathrm{MeOH}$ to quench the reaction. Afterwards, samples were filtered through a Whatman Uniflo Syringe Filter with a polypropylene overmold housing $(0.22 \mu \mathrm{m}$, Whatman, UK), and the filtrate was analyzed using liquid chromatography. In most cases, experiments were repeated twice, and mean values are quoted as results. It is worth noting that the variance between measurements never exceeded $5 \%$.

For the recycle/reusability experiments, the catalyst was collected at the end of each cycle, filtered, and washed with deionized water several times. Then, it was dried at $60^{\circ} \mathrm{C}$ overnight and employed into the next cycle.

The kinetics of SMX degradation were fitted to a pseudo-first-order model and the apparent rate constant (k) was calculated as follows (Equation (1)):

$$
-\operatorname{Ln}\left(C / C_{0}\right)=k t
$$


where $\mathrm{C}_{0}$ and $\mathrm{C}_{\mathrm{t}}$ are the SMX concentrations at the beginning and at a specific reaction time $(\mathrm{t})$, respectively.

\subsection{Chemical Analysis}

The residual SMX concentration was determined by high performance liquid chromatography (HPLC, Waters Alliance 2695, MA, USA) equipped with a photo diode array detector (PDA, Waters 2996). SMX was detected at $270 \mathrm{~nm}$ using a mobile phase consisting of $\mathrm{ACN}: 0.1 \% \mathrm{H}_{3} \mathrm{PO}_{4}$ UPW (15:85, $v / v)$ mixture at a flow rate of $200 \mu \mathrm{L} / \mathrm{min}$ on a Kinetex C18 column $(50 \mathrm{~mm} \times 2.1 \mathrm{~mm}$, i.d. $2.6 \mu \mathrm{m})$.

\section{Conclusions}

The present study proposed a nickel-containing perovskite material as SPS activator. The major findings are as follows:

- LNO possesses high efficiency as a persulfate activator and can be adopted in water decontamination processes.

- The SMX degradation rate can be effectively tuned by adjusting SMX, SPS, and LNO loadings.

- The efficiency is favored in almost neutral conditions ( $\mathrm{pH}$ 6), thus making it an environmentally friendly process.

- Bicarbonate ions and organic matter present in aqueous media suppress the activity of LNO/SPS system.

- $\quad$ LNO can be effectively used in repeated experimental runs, showing excellent stability thus proving the true catalytic nature of the proposed system.

Supplementary Materials: The following are available online at http://www.mdpi.com/2073-4344/10/12/1373/s1, Figure S1. Effect of catalyst dosage: $\operatorname{Ln}\left(C / C_{0}\right)$ as a function of time through linear regression. Experimental conditions: $\mathrm{C}_{\mathrm{SMX}}=500 \mu \mathrm{g} / \mathrm{L} ; \mathrm{C}_{\mathrm{SPS}}=100 \mathrm{mg} / \mathrm{L} ; \mathrm{pH}=6$; room temperature. Table S1. Main properties of the actual water matrices used in this study.

Author Contributions: Conceptualization, A.P.; Writing. A.P. and O.S.A.; Investigation, O.S.A. and M.C.; Methodology, A.S.; Supervision. Z.F. and D.M. All authors have read and agreed to the published version of the manuscript.

Funding: This research was funded by H.F.R.I., the Hellenic Foundation for Research and Innovation and General Secretariat for Research and Technology (GSRT). This work is part of the project "2De4P: Development and Demonstration of a Photocatalytic Process for removing Pathogens and Pharmaceuticals from wastewaters" which is implemented under the Action "H.F.R.I.-1st Call for Research Projects to Support Post-Doctoral Researchers", funded by H.F.R.I. Hellenic Foundation for Research and Innovation and General Secretariat for Research and Technology (GSRT).

Acknowledgments: The authors wish to thank K. Govatsi and M. Kollia staff of the Laboratory of Electron Microscopy and Microanalysis (L.E.M.M.) at University of Patras for SEM and TEM images.

Conflicts of Interest: The authors declare no conflict of interest.

\section{References}

1. Giwa, A.; Yusuf, A.; Balogun, H.A.; Sambudi, N.S.; Bilad, M.R.; Adeyemi, I.; Chakraborty, S.; Curcio, S. Recent advances in advanced oxidation processes for removal of contaminants from water: A comprehensive review. Process Saf. Environ. Prot. 2021, 146, 220-256. [CrossRef]

2. Arthur, R.B.; Ahern, J.C.; Patterson, H.H. Application of BiOX photocatalysts in remediation of persistent organic pollutants. Catalysts 2018, 8, 604. [CrossRef]

3. Sarmento, A.P.; Carraro Borges, A.; Teixeira de Matos, A.; Lucílio Romualdo, L. Sulfamethoxazole and trimethoprim degradation by Fenton and Fenton-like processes. Water 2020, 12, 1655. [CrossRef]

4. Pierpaoli, M.; Szopińska, M.; Wilk, B.K.; Sobaszek, M.; Łuczkiewicz, A.; Bogdanowicz, R.; Fudala-Książek, S. Electrochemical oxidation of PFOA and PFOS in landfill leachates at low and highly boron-doped diamond electrodes. J. Hazard. Mater. 2021, 403, 123606. [CrossRef] 
5. Giannakis, S.; Lin, K.-Y.A.; Ghanbari, F. A review of the recent advances on the treatment of industrial wastewaters by sulfate radical-based Advanced Oxidation Processes (SR-AOPs). Chem. Eng. J. 2021, 406, 127083. [CrossRef]

6. Magioglou, E.; Frontistis, Z.; Vakros, J.; Manariotis, I.D.; Mantzavinos, D. Activation of persulfate by biochars from valorized olive stones for the degradation of sulfamethoxazole. Catalysts 2019, 9, 419. [CrossRef]

7. Graça, C.A.L.; Velosa, A.C.; Teixeira, A.S.C. Amicarbazone degradation by UVA-activated persulfate in the presence of hydrogen peroxide or $\mathrm{Fe}^{2+}$. Catal. Today 2017, 280, 80-85. [CrossRef]

8. Wacławek, S.; Lutze, H.V.; Grübel, K.; Padil, V.V.T.; Černík, M.; Dionysiou, D.D. Chemistry of persulfates in water and wastewater treatment: A review. Chem. Eng. J. 2017, 330, 44-62. [CrossRef]

9. Luo, C.; Ma, J.; Jiang, J.; Liu, Y.; Song, Y.; Yang, Y.; Guan, Y.; Wu, D. Simulation and comparative study on the oxidation kinetics ofatrazine by $U V / \mathrm{H}_{2} \mathrm{O}_{2}, U V / \mathrm{HSO}_{5}{ }^{-}$and $U V / \mathrm{S}_{2} \mathrm{O}_{8}{ }^{-}$. Water Res. 2015, 80, 99-108. [CrossRef]

10. Guo, P.-C.; Qiu, H.-B.; Yang, C.-W.; Zhang, X.; Shao, X.-Y.; Lai, Y.-L.; Sheng, G.-P. Highly efficient removal and detoxification of phenolic compounds using persulfate activated by MnOx@OMC: Synergistic mechanism and kinetic analysis. J. Hazard. Mater. 2021, 402, 123846. [CrossRef]

11. Chen, F.; Huang, G.-X.; Yao, F.-B.; Yang, Q.; Zheng, Y.-M.; Zhao, Q.-B.; Yu, H.-Q. Catalytic degradation of ciprofloxacin by a visible-light-assisted peroxymonosulfate activation system: Performance and mechanism. Water Res. 2020, 173, 115559. [CrossRef] [PubMed]

12. Zhang, T.; Chen, Y.; Wang, Y.; Le Roux, J.; Yang, Y.; Croué, J.-P. Efficient peroxydisulfate activation process not relying on sulfate radical generation for water pollutant degradation. Environ. Sci. Technol. 2014, 48, 5868-5875. [CrossRef] [PubMed]

13. Lei, Y.; Chen, C.-S.; Tu, Y.-J.; Huang, Y.-H.; Zhang, H. Heterogeneous degradation of organic pollutants by persulfate activated by $\mathrm{CuO}-\mathrm{Fe}_{3} \mathrm{O}_{4}$ : Mechanism, stability, and effects of $\mathrm{pH}$ and bicarbonate ions. Environ. Sci. Technol. 2015, 49, 6838-6845. [CrossRef] [PubMed]

14. Alexopoulou, C.; Petala, A.; Frontistis, Z.; Drivas, C.; Kennou, S.; Kondarides, D.I.; Mantzavinos, D. Copper phosphide and persulfate salt: A novel catalytic system for the degradation of aqueous phase micro-contaminants. Appl. Catal. B Environ. 2019, 244, 178-187. [CrossRef]

15. Gkika, C.; Petala, A.; Frontistis, Z.; Bampos, G.; Hela, D.; Konstantinou, I.; Mantzavinos, D. Heterogeneous activation of persulfate by lanthanum strontium cobaltite for sulfamethoxazole degradation. Catal. Today 2020. [CrossRef]

16. Zhu, J.; Li, H.; Zhong, L.; Xiao, P.; Xu, X.; Yang, X.; Zhao, Z.; Li, J. Perovskite oxides: Preparation, characterizations, and applications in heterogeneous catalysis. ACS Catal. 2014, 4, 2917-2940. [CrossRef]

17. Su, C.; Wang, W.; Chen, Y.; Yang, G.; Xu, X.; Tadé, M.O.; Shao, Z. $\mathrm{SrCo}_{0.9} \mathrm{Ti}_{0.1} \mathrm{O}_{3-\delta}$ as a new electrocatalyst for the oxygen evolution reaction in alkaline electrolyte with stable performance. ACS Appl. Mater. Interfaces 2015, 7, 17663-17670. [CrossRef]

18. Kumar, A.; Kumar, A.; Krishnan, V. Perovskite oxide-based materials for energy and environment-oriented photocatalysis. ACS Catal. 2020, 10, 10253-10315. [CrossRef]

19. Hammouda, S.B.; Zhao, F.; Safaei, Z.; Srivastava, V.; Ramasamy, D.L.; Iftekhar, S.; Kalliola, S.; Sillanpaa, M. Degradation and mineralization of phenol in aqueous medium by heterogeneous monopersulfate activation on nanostructured cobalt based-perovskite catalysts $\mathrm{ACoO}_{3}(\mathrm{~A}=\mathrm{La}, \mathrm{Ba}, \mathrm{Sr}$ and $\mathrm{Ce})$ : Characterization, kinetics and mechanism study. Appl. Catal. B Environ. 2017, 215, 60-73. [CrossRef]

20. Miao, J.; Sunarso, J.; Su, C.; Zhou, W.; Wang, S.; Shao, Z. SrCo $\mathrm{SO}_{1-\mathrm{x}} \mathrm{TiO}_{3-\delta}$ perovskites as excellent catalysts for fast degradation of water contaminants in neutral and alkaline solutions. Sci. Rep. 2017, 7, 44215-44224. [CrossRef]

21. Pang, X.; Guo, Y.; Zhang, Y.; Xu, B.; Qi, F. $\mathrm{LaCoO}_{3}$ perovskite oxide activation of peroxymonosufate for aqueous 2-phenyl-5-sulfobenzimidazole degradation: Effect of synthetic method and the reaction mechanism. Chem. Eng. J. 2016, 304, 897-907. [CrossRef]

22. Jiang, L.; Xu, X.; Yan, J.; Zuo, Y.; Tao, Y.; Yao, D.; He, G.; Chen, H. Heterogeneous activation of persulfate for the degradation of bisphenol A with $\mathrm{Ni}_{2} \mathrm{SnO}_{4}-\mathrm{RGO}$. New J. Chem. 2020, 44, 6355-6361. [CrossRef]

23. Wu, Z.; Liang, Y.; Zou, D.; Yuan, X.; Xiao, Z.; Deng, Y.; Zhou, Y.; Jiang, L.; Qin, P. Enhanced heterogeneous activation of persulfate by $\mathrm{Ni}_{\mathrm{x}} \mathrm{Co}_{3-\mathrm{x}} \mathrm{O}_{4}$ for oxidative degradation of tetracycline and bisphenol A. J. Environ. Chem. Eng. 2020, 8, 104451. [CrossRef] 
24. Rehman, S.U.; Shaur, A.; Song, R.-H.; Lim, T.-H.; Hong, J.-E.; Park, S.-J.; Lee, S.-B. Nano-fabrication of a high-performance $\mathrm{LaNiO}_{3}$ cathode for solid oxide fuel cells using an electrochemical route. J. Power Source 2019, 429, 97-104. [CrossRef]

25. Petrie, J.R.; Cooper, V.R.; Freeland, J.W.; Meyer, T.L.; Zhang, Z.; Lutterman, D.A.; Lee, H.N. Enhanced bifunctional oxygen catalysis in strained $\mathrm{LaNiO}_{3}$ perovskites. J. Am. Chem. Soc. 2016, 138, 2488-2491. [CrossRef]

26. Zhang, J.; Zhao, Y.; Zhao, X.; Liu, Z.; Chen, W. Porous perovskite $\mathrm{LaNiO}_{3}$ nanocubes as cathode catalysts for Li-O ${ }_{2}$ batteries with low charge potential. Sci. Rep. 2014, 4, 6005. [CrossRef]

27. Yang, X.; Liu, Y.; Li, S.; Wei, X.; Wang, L.; Chen, Y. A direct borohydride fuel cell with a polymer fiber membrane and non-noble metal catalysts. Sci. Rep. 2012, 2, 567. [CrossRef]

28. Kostopoulou, A.; Brintakis, K.; Nasikas, N.K. Perovskite nanocrystals for energy conversion and storage. Nanophotonics 2019, 8, 1607-1640. [CrossRef]

29. Hwang, D.K.; Kim, S.; Lee, J.H.; Hwang, I.-S.; Kim, I.-D. Phase evolution of perovskite $\mathrm{LaNiO}_{3}$ nanofibers for supercapacitor application and p-type gas sensing properties of $\mathrm{LaOCl}-\mathrm{NiO}$ composite nanofibers. J. Mater. Chem. 2011, 21, 1959-1965. [CrossRef]

30. Royer, S.; Duprez, D.; Can, F.; Courtois, X.; Batiot-Dupeyrat, C.; Laassiri, S.; Alamdari, H. Perovskites as substitutes of noble metals for heterogeneous catalysis: Dream or reality. Chem. Rev. 2014, 114, 10292-10368. [CrossRef]

31. Lv, T.; Wu, M.; Guo, M.; Liu, Q.; Jia, L. Self-assembly photocatalytic reduction synthesis of graphene-encapusulated $\mathrm{LaNiO}_{3}$ nanoreactor with high efficiency and stability for photocatalytic water splitting to hydrogen. Chem. Eng. J. 2019, 356, 580-591. [CrossRef]

32. Abellan, M.N.; Bayarri, B.; Gimenez, J.; Costa, J. Photocatalytic degradation of sulfamethoxazole in aqueous suspension of $\mathrm{TiO}_{2}$. Appl. Catal. B Environ. 2007, 74, 233-241. [CrossRef]

33. Tsiampalis, A.; Frontistis, Z.; Binas, V.; Kiriakidis, G.; Mantzavinos, D. Degradation of sulfamethoxazole using iron-doped titania and simulated solar radiation. Catalysts 2019, 9, 612. [CrossRef]

34. Yang, Y.; Lu, X.; Jiang, J.; Ma, J.; Liu, G.; Cao, Y.; Liu, W.; Li, J.; Pang, S.; Kong, X.; et al. Degradation of sulfamethoxazole by $\mathrm{UV}, \mathrm{UV} / \mathrm{H}_{2} \mathrm{O}_{2}$ and $\mathrm{UV} /$ persulfate (PDS): Formation of oxidation products and effect of bicarbonate. Water Res. 2017, 118, 169-207. [CrossRef] [PubMed]

35. Safakas, A.; Bampos, G.; Bebelis, S. Oxygen reduction reaction on $\mathrm{La}_{0.8} \mathrm{Sr}_{0.2} \mathrm{Co}_{x} \mathrm{Fe}_{1-\mathrm{x}} \mathrm{O}_{3-\delta}$ perovskite/carbon black electrocatalysts in alkaline medium. Appl. Catal. B Environ. 2019, 244, 225-232. [CrossRef]

36. Wang, T.; Qian, X.; Yue, D.; Yan, X.; Yamashita, H.; Zhao, Y. CaMnO 3 Perovskite Nanocrystals for Efficient Peroxydisulfate Activation. Chem. Eng. J. 2020, 398, 125638. [CrossRef]

37. Lu, S.; Wang, G.; Chen, S.; Yu, H.; Ye, F.; Quan, X. Heterogeneous activation of peroxymonosulfate by $\mathrm{LaCo}_{1-\mathrm{x}} \mathrm{Cu}_{\mathrm{x}} \mathrm{O}_{3}$ perovskites for degradation of organic pollutants. J. Hazard. Mater. 2018, 353, 401-409. [CrossRef]

38. Liu, L.; Lin, S.; Zhang, W.; Farooq, U.; Shen, G.; Hu, S. Kinetic and mechanistic investigations of the degradation of sulfachloropyridazine in heat-activated persulfate oxidation process. Chem. Eng. J. 2018, 346, 515-524. [CrossRef]

39. Arvaniti, O.S.; Frontistis, Z.; Nika, M.C.; Aalizadeh, R.; Thomaidis, N.S.; Mantzavinos, D. Sonochemical degradation of trimethoprim in water matrices: Effect of operating conditions, identification of transformation products and toxicity assessment. Ultrason. Sonochem. 2020, 67, 105139. [CrossRef]

40. Lebik-Elhadi, H.; Frontistis, Z.; Ait-Amar, H.; Amrani, S.; Mantzavinos, D. Electrochemical oxidation of pesticide thiamethoxam on boron doped diamond anode: Role of operating parameters and matrix effect. Process Saf. Environ. 2018, 116, 535-541. [CrossRef]

41. Pu, M.; Niu, J.; Brusseau, M.L.; Sun, Y.; Zhou, C.; Deng, S.; Wan, J. Ferrous metal-organic frameworks with strong electron-donating properties for persulfate activation to effectively degrade aqueous sulfamethoxazole. Chem. Eng. J. 2020, 394, 125044. [CrossRef]

42. Wu, Y.; Shi, Y.; Chen, H.; Zhao, J.; Dong, W. Activation of persulfate by magnetite: Implications for the degradation of low concentration sulfamethoxazole. Process Saf. Environ. 2018, 116, 468-476. [CrossRef]

43. Shen, B.; Liu, Y.; Liu, S.; Tan, X.; Zhang, P.; Du, L.; Wen, J. Catalytic degradation of sulfamethoxazole by persulfate activated with magnetic graphitized biochar: Multiple mechanisms and variables effects. Process Saf. Environ. 2020, 144, 143-157. [CrossRef] 
44. Oh, W.-D.; Dong, Z.; Ronn, G.; Lim, T.-T. Surface-active bismuth ferrite as superior peroxymonosulfate activator for aqueous sulfamethoxazole removal: Performance, mechanism and quantification of sulfate radical. J. Hazard. Mater. 2017, 325, 71-81. [CrossRef] [PubMed]

45. Bao, Y.; Lim, T.-T.; Wang, R.; Webster, R.D.; Hu, X. Urea-assisted one-step synthesis of cobalt ferrite impregnated ceramic membrane for sulfamethoxazole degradation via peroxymonosulfate activation. Chem. Eng. J. 2018, 343, 737-747. [CrossRef]

46. Yanan, S.; Xing, X.; Yue, Q.; Gao, B.; Li, Y. Nitrogen-doped carbon nanotubes encapsulating Fe/Zn nanoparticles as persulfate activator for sulfamethoxazole degradation: Role of encapsulated bimetallic nanoparticles and nonradical reaction. Environ. Sci. Nano 2020, 7, 1444-1453. [CrossRef]

47. Wang, H.; Guo, W.; Yin, R.; Du, J.; Wu, Q.; Luo, H.; Liu, B.; Sseguya, F.; Ren, N. Biochar-induced Fe (III) reduction for persulfate activation in sulfamethoxazole degradation: Insight into the electron transfer, radical oxidation and degradation pathways. Chem. Eng. J. 2019, 362, 561-569. [CrossRef]

48. Qiang, Z.; Adams, C. Potentiometric determination of acid dissociation constants (pKa) for human and veterinary antibiotics. Water Res. 2004, 38, 2874-2890. [CrossRef]

49. Haman, C.; Dauchy, X.; Rosin, C.; Munoz, J.-F. Occurrence, fate and behavior of parabens in aquatic environments: A review. Water Res. 2015, 68,1-11. [CrossRef]

50. Ziylan, A.; Ince, N.H. The occurrence and fate of anti-inflammatory and analgesic pharmaceuticals in sewage and fresh water: Treatability by conventional and non-conventional processes. J. Hazard. Mater. 2011, 187, 24-36. [CrossRef]

51. Guo, H.; Zhou, X.; Zhang, Y.; Yao, Q.; Qian, Y.; Chu, H.; Chen, J. Carbamazepine degradation by heterogeneous activation of peroxymonosulfate with lanthanum cobaltite perovskite: Performance, mechanism and toxicity. J. Environ. Sci. 2020, 91, 10-21. [CrossRef]

52. Qi, F.; Chu, W.; Xu, B. Modeling the heterogeneous peroxymonosulfate/Co-MCM41 process for the degradation of caffeine and the study of influence of cobalt sources. Chem. Eng. J. 2014, 235, 10-18. [CrossRef]

53. Lin, K.Y.A.; Chen, Y.C.; Lin, Y.F. $\mathrm{LaMO}_{3}$ perovskites $(\mathrm{M}=\mathrm{Co}, \mathrm{Cu}, \mathrm{Fe}$ and $\mathrm{Ni})$ as heterogeneous catalysts for activating peroxymonosulfate in water. Chem. Eng. Sci. 2017, 160, 96-105. [CrossRef]

54. Wang, C.; Gao, S.; Zhu, J.; Xia, X.; Wang, M.; Xiong, Y. Enhanced activation of peroxydisulfate by strontium modified $\mathrm{BiFeO}_{3}$ perovskite for ciprofloxacin degradation. J. Environ. Sci. 2021, 99, 249-259. [CrossRef] [PubMed]

55. Al Hakim, S.; Baalbaki, A.; Tantawi, O.; Ghauch, A. Chemically and thermally activated persulfate for theophylline degradation and application to pharmaceutical factory effluent. RSC Adv. 2019, 9, 33472-33485. [CrossRef]

56. Feng, Y.; Song, Q.; Lv, W.; Liu, G. Degradation of ketoprofen by sulfate radical-based advanced oxidation processes: Kinetics, mechanisms, and effects of natural water matrices. Chemosphere 2017, 189, 643-651. [CrossRef]

57. Anipsitakis, G.P.; Dionysiou, D.D. Radical generation by the interaction of transition metals with common oxidants. Environ. Sci. Technol. 2004, 38, 3705-3712. [CrossRef]

58. Neta, P.; Madhavan, V.; Zemel, H.; Fessenden, R. Rate constants and mechanism of reaction of $\mathrm{SO}_{4}{ }^{\bullet-}$ with aromatic compounds. J. Am. Chem. Soc. 1977, 99, 163-164. [CrossRef]

59. Su, C.; Duan, X.; Miao, J.; Zhong, Y.; Zhou, W.; Wang, S.; Shao, Z. Mixed conducting perovskite materials as superior catalysts for fast aqueous-phase advanced oxidation: A mechanistic study. ACS Catal. 2017, 7, 388-397. [CrossRef]

60. Cullity, B.D. Elements of X-ray Diffraction; Addison-Wesley Publishing Company, Inc., Reading: Boston, MA, USA, 1956.

Publisher's Note: MDPI stays neutral with regard to jurisdictional claims in published maps and institutional affiliations. 